\title{
The Utilization of Durian Seeds (Durio Zibethinus Murr) as a Base for Making Edible Film
}

\author{
Sitti Rahmawati*, Alfiana Aulia, Nur Hasfah, Siti Nuryanti, Paulus Hengky Abram, Purnama Ningsih \\ Chemistry Study Program, Faculty of Teacher Training and Education, Tadulako University, Palu 94118, Indonesia
}

Corresponding Author Email: sittirahmawati.untad@gmail.com

https://doi.org/10.18280/ijdne.160110

Received: 2 January 2021

Accepted: 18 February 2021

\section{Keywords:}

edible film, glycerol, sorbitol, plasticizer

\begin{abstract}
Starch is one of the basic ingredients for making edible films (edible coatings), but it tears easily, so it needs the addition of plasticizers. This study aims to make edible film from durian seed starch (Durio zibethinus Murr) with the addition of plasticizers, glycerol and sorbitol and determine its characterization. The results showed that the best edible film was produced by adding $2.5 \%(\mathrm{w} / \mathrm{v})$ of glycerol and $2 \%(\mathrm{w} / \mathrm{v})$ of sorbitol. The physical characteristics of the edible film are respectively: thickness $0.1700 \mathrm{~mm}$ and $0.1633 \mathrm{~mm}$, tensile strength $0.008 \mathrm{Kgf} / \mathrm{mm}^{2}$ and $0.010 \mathrm{Kgf} / \mathrm{mm}^{2}$, percent elongation $42.76 \%$ and $37.13 \%$, elasticity 0.0202 and 0.0272 . The chemical characteristics of edible film include: water absorption test of $58.22 \%$ and $60.43 \%$, solubility of $40.89 \%$ and $26.42 \%$, water vapor transmission rates of $0.2275 \mathrm{~g} / \mathrm{jamm}^{2}$ and $0.3127 \mathrm{~g} / \mathrm{jamm}^{2}$, and $\mathrm{pH} 6.90$ and 7.85. The results of functional group analysis (FTIR) show that the process of making edible films in this study is a physical mixing process. The shelf life of edible films at room temperature is 5 days and at cold temperature for 7 days. The biodegradability test showed that the edible film in this study could be completely degraded within 7 days. This shows that the durian seed starch edible film is an environmentally friendly packaging.
\end{abstract}

\section{INTRODUCTION}

Asia continent is the biggest plastic consumer in the world which absorbs around 30\% of plastic consumption and followed by America Continent, Europe Continent, and other countries. Indonesia is the second rank in the world as waste contributor after China. Plastic is used in various life sectors. Every year around 100 million tons plastics are produced in the world to be used in various industrial sectors [1]. Plastic as the packaging material is widely used as food wrapper, food and drink mat, for school needs, office, automotive, and various other sectors [2]. This material stability continues to develop until its trait is proof towards microorganism degradation [3]. This causes environmental pollution because of its decomposition takes process more or less $10-12$ years. The average consumption of plastic per capita in advanced countries is around $80-100 \mathrm{Kg}$ per year [4].

Based on that problem, then alternative and friendly environment plastics made of decomposable material in the environment are needed and available in big amount in the nature and capable of producing product with the same strength with synthetic plastics [5]. One of packaging type that is environmentally friendly is edible packaging. Edible packaging is the packaging that can be eaten because it is made of materials that can be eaten such as starch, protein, and fat. The making edible films, researchers used durian seed starch as the basic ingredient, arguing that durian seed starch contains a lot of carbohydrates and protein [6]. In addition to having a high starch content, durian seeds are widely available in Central Sulawesi, based on data from the Central Sulawesi BPS in 2018, durian fruit production is in second place after bananas as much as $17,623,872 \mathrm{~kg} /$ year [7]. Durian seeds are a food waste whose utilization is less than optimal and is still widely disposed of by the community. Durian seeds have a high starch content, which is around $42.1 \%$, so they can be used as a basic material for making edible films [6]. Apart from acting as packaging for foodstuffs, edible films can also function as carriers for antioxidant compounds and are able to inhibit oxidation in packaged foods [8].

There are many researches that had been conducted about Edible Film such as the making and characterization of Edible Film from starch polyblend of sukun-polyvinil alcohol with propylene glycol as plasticizer. In general, the characterization result of the best Edible Film is at comparison of sukunpolyvinil alcohol starch 1:2 with thickness $0.47 \mathrm{~mm}$, water content $15.5580 \%$; pH 7.10 ; tensile strength test 17,1239 $\mathrm{N} / \mathrm{mm}^{2}$, elongation percentage $49.67 \%$ and the speed of water vapor transmission in the amount of $0.1464 \mathrm{mg} / \mathrm{jamcm}^{2}$. The kind of another starch material that its utilization had been investigated as edible film is starch from the skin of cassava and chicken feather keratin, and the starch of banana skin. The research results show that keratin addition towards edible film plastic gives effect towards film visual, the more increase of keratin addition concentration, then the film color will be brownish, tensile strength will increase more and elongation will decrease and edible film produced can be accepted as wrapping plastic [9]. Another starch material is potato starch (Solanum Tuberosum L) with Glycerol addition as plasticizer. Edible film characteristic from potato starch with Glycerol addition 20, 30 and $40 \%(\mathrm{v} / \mathrm{v})$ gives thickness values respectively $0.058 \mathrm{~mm}, 0.062 \mathrm{~mm}$, and $0.071 \mathrm{~mm}$ and tensile strength value is $0.75 ; 0.69$; and $0.35 \mathrm{~N} / \mathrm{mm}^{2}$ [10]. The best treatment in the making and characterization of Banggai Tuber (Dioscorea spp) edible film with the usage $80^{\circ} \mathrm{C}$ temperature 
and glycerol in the amount of $2 \%(\mathrm{~b} / \mathrm{v})$ and sorbitol $2 \%(\mathrm{~b} / \mathrm{v})$ [2].

Based the background and the research which had been conducted, there is still no research about starch taken from durio seeds to be used as raw material of making edible film. This research aimed to make edible film and analyzed the characterization of edible film Durio Seeds (Durio zibethinus murr) starch based

\section{METHOD}

\subsection{Preparation of durian seeds starch}

Durian in the amount of $2 \mathrm{Kg}$ durio seeds were peeled and cleaned. Then the durio seeds was cut into small pieces and rinsed by using aquades. Durio seeds pieces were then put into blender with low speed and solution of Natrium Bisulfite $0.230 \%$ (2, 3 grams of natrium bisulfite and 2 liters of aquades) until smooth then rinsed with aquades and squeezed by using cloth with small pore. The squeezing is repeated for a couple of times until it does not release water anymore. The squeezed water was then left 24 hours and throw away the pulp squeeze. The sediment obtained from one day sinking then was washed by using aquades and filtered by using Buchner filter. Then, durian seeds sediment that had been cleared was dried in the oven at $50^{\circ} \mathrm{C}$ temperature for 24 hours until the sediment is dry. After that, the dry sediment then was put into blender or pounded and sifted by using 100 mesh sifters, then dry durian seeds starch is obtained. The starch then was kept in room temperature in the closed container [11].

\subsection{Preparation of edible film from durio seeds starch}

The Edible film was made by weighing durian seeds starch with weight 3 gram then added by each $1.5 \mathrm{ml}, 2 \mathrm{ml}$, and 2.5 $\mathrm{ml}$ glycerol. Each durian seeds starch and glycerol are heated on the hot plate stirrer with mixture of $80 \mathrm{ml}$ aquades at $80^{\circ} \mathrm{C}$ temperature for 15 minutes. Then, add 1 gram $\mathrm{CMC}$ altogether with $20 \mathrm{ml}$ aquades addition. Afterwards, heat it again at $90^{\circ} \mathrm{C}$ temperature for 7 minutes. The print is conducted by pouring $100 \mathrm{ml}$ solution at glass plate sized $25 \times 16 \times 2 \mathrm{~cm}$. After the solution is dry, the print is taken from the oven then cooled at room temperature for 10 minutes. Then the formed skin layer was peeled using the assistance of spatula and put into or kept in desiccator. Do the same treatment by replacing glycerol to sorbitol [12].

\subsection{Edible film characterization}

\subsubsection{Thickness test of edible film}

Sample thickness of edible film was measured by using micrometer at 5 different places with $0.01 \mathrm{~mm}$ accuracy [10]. The result of average measurement is as the result of film thickness. The measurement was conducted to 6 produced samples.

2.3.2 Tensile strength test, percentage of elongation and elasticity

Tensile strength is the maximum force that can be detained by edible film until broken off while elongation percentage is the change of maximum elongation which can be experienced by the material when it experienced elongation or pulled until before the material is broken off. The tensile strength, the test was conducted pairing the sample at the top part of the grip and the bottom part. The recorder value was set at zero, the test was started by pressing RETURN button for restoring the grip to the original position. The sample size used for this test was $8 \times 4 \mathrm{~cm}(80 \mathrm{~mm} \times 40 \mathrm{~mm})$ with tensile strength accuracy was $700 \mathrm{~mm} /$ minute, grip weight $=50 \mathrm{~N} / 5 \mathrm{Kgf}$, sample wide $(\mathrm{A})=(80 \times 40) \mathrm{mm}^{2}[13]$.

$$
\text { Tensile strength }\left(\mathrm{N} / \mathrm{mm}^{2}\right)=\frac{\mathrm{F} \max }{\mathrm{A}}
$$

in which,

$$
\begin{aligned}
\mathrm{F} \max & =\text { Sample tensile value }(\mathrm{N}) \\
\mathrm{A} & =\text { Sample wide }\left(\mathrm{mm}^{2}\right)
\end{aligned}
$$

Elongation was used to see the maximal food of edible film before it was broken off at tensile strength test. The sample elongation was read automatically in the form of film elongation difference $=\Delta \mathrm{L}(\mathrm{mm})$ [13]. While for elasticity was obtained from the comparison between tensile strength and elongation [7].

$$
\% \text { Elongation }=\frac{\Delta \mathrm{L}}{\mathrm{Lo}} \times 100 \%
$$

in which,

$$
\begin{gathered}
\Delta \mathrm{L}=\text { Difference of film elongation } \\
\text { Lo }=\text { Film original length }
\end{gathered}
$$

\subsubsection{Functional group analysis with FTIR (Fourier Transform Infrared Spectroscopy)}

Functional Group Analysis with FTIR aims to know the process which occurs at the mixture if physically or chemically therefore the sample at each process of making edible film was analyzed by using FTIR. The sample was placed into set holder, then find the right spectrum. The result will obtain correlation diffractogram between wave number and intensity. FTIR Spectrum was recorded by using spectrophotometer at room temperature [14].

\subsection{4 $\mathrm{pH}$ test}

This examination was conducted using $\mathrm{pH}$ meter. $\mathrm{pH}$ measurement was conducted by 1 gram edible film is dissolved into $10 \mathrm{~mL}$ aquades in petri dish. Electrode is dipped into the dish containing edible film solution then see it until reaching the number showed by $\mathrm{pH}$ mEther. Do it on each sample [13].

\subsubsection{Biodegradibility test}

Biodegradation test (decomposability of bioplastic) was conducted by sinking edible film sample into EM4 (Effective Microorganism 4). EM4 Bacteria used was the bacteria for fermentation of soil organic material. EM4 contained fermentation bacteria from Lactobacillus genus, fermented mushroom, actinomycete photosynthetic bacteria, phosphate solvents bacteria, and yeast [15].

\subsubsection{Water absorption test}

Absorption test of edible film was conducted by weighing 2 gram edible film sample, then weighed the initial weight (D), then dipped into container containing aquades for 10 seconds then they took out the sample from the container and the water that still sticked to edible film surface was diminished by using 
tissue, then do weighing to obtain the final weight of the sample (C). The sample was dipped again into the container containing aquades for 10 seconds then lifted and weighed again. The procedure of dipping and weighing was conducted continuously until the final weight of the sample is constant. The percentage of water absorption can be counted through the equation as follows [16]:

$$
\% \text { Water Absorption }=\frac{C-D}{D} \times 100 \%
$$

\subsubsection{Solubility test of edible film}

Solubility test was conducted by weighing 2 gram edible film sample, then put into the oven using cup with temperature $100^{\circ} \mathrm{C}$ for 30 minutes. Then the film was weighed as initial weight (B), then edible film was soaked for 24 hours, the film which was not dissolved then lift and dried into oven for two hours with temperature $100^{\circ} \mathrm{C}$. The film was taken and put into desiccator for 10 minutes. Then weighed again to obtain the weight of dry edible film after the soaking (D). The solution percentage of edible film can be counted by using the equation as follows [17]:

$$
\% \text { film solubility }=\frac{B-D}{B} \times 100 \%
$$

2.3.8 The speed of water vapor transmission gravimetry method

The speed of water vapor transmission towards edible film was measured by using porcelain cup. Before measured, the room in desiccator was conditioned at humidity which has $\mathrm{RH}$ $75 \%$ by putting the solution of salt $\mathrm{NaCl} 40 \%$. In the porcelain cup, put in 5 gram silica gel that had been activated and 3 gram edible film then partitioned until there is no gap at its bank. Then, the porcelain cup was weighed with accuracy 0.0001 gram then put into desiccator that had been conditioned, then closed tightly. Every hour for 5 hours, determine the score of water vapor transmission in the porcelain cup which pass through edible film and counted by using formula:

$$
\mathrm{WvTR}=\frac{\mathrm{Mv}}{\mathrm{t} \cdot \mathrm{A}}
$$

$$
\begin{aligned}
& \text { Description: } \\
& \begin{array}{ll}
\mathrm{Mv} & =\text { Addition/reduction of vapor mass (gram) } \\
\mathrm{t} & =\text { Weighing period (hour) } \\
\mathrm{A} & =\text { Wide of Edible Film tested }\left(\mathrm{cm}^{2}\right)[18] .
\end{array}
\end{aligned}
$$

\subsubsection{Shelf-life test}

Shelf-life test is determined by using acceleration method. This test was conducted after knowing the optimum composition in making edible film. Edible film plastic then was applied for wrapping apple/potato that had been prepared in accordance with the treatment such as the first treatment is saving it in the open room $\left(30^{\circ} \mathrm{C}\right)$ there are three packaging variations: $\mathrm{K}_{1}$ (without packaging), $\mathrm{K}_{2}$ (wrapped by edible film), and $K_{3}$ (wrapped by using greaseproof paper). The second treatment was saving it in the cooler room $\left(16^{\circ} \mathrm{C}\right)$. There are 2 packaging variations: $\mathrm{K}_{\mathrm{o}}$ (without packaging), and $\mathrm{K}_{1}$ (wrapped by edible film) [6]

\section{RESULTS \& DISCUSSION}

The basic material for making edible film used in this research was starch taken from durio seeds until obtained dry durio seeds starch (Figure 1).

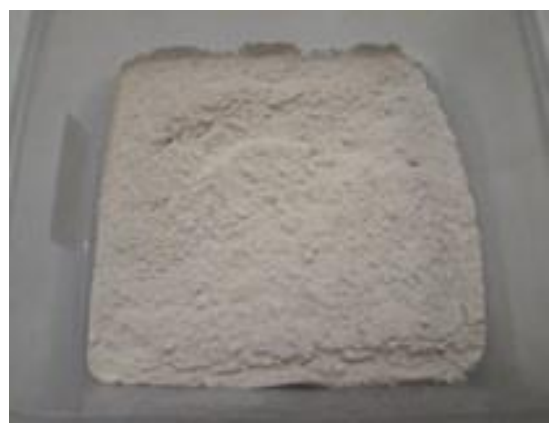

Figure 1. Durio seeds starch

The making edible films from Durio Seeds starch, variations of plastizer are done, namely glycerol and sorbitol. Edible films produced from the formula of Durio Seeds starch, CMC, glycerol $(1.5 ; 2 ; 2.5) \mathrm{mL}$ and sorbitol $(1.5 ; 2 ; 2.5) \mathrm{mL}$ can be seen in Figure 2 .

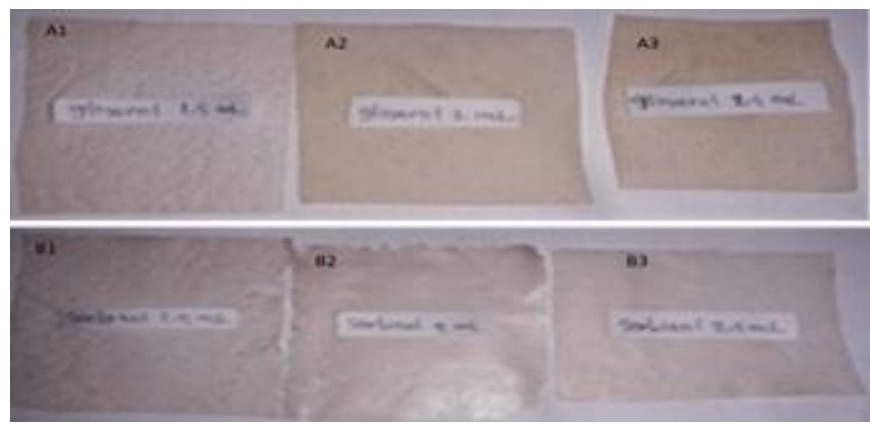

Figure 2. Edible film durio seeds starch after addition: (A) Glycerol, and (B) Sorbitol

\subsection{Characterization of edible film from durio seeds starch}

\subsubsection{The test of edible film thickness}

The value of edible film thickness of durio seeds starch produced can be seen in Figure 3:

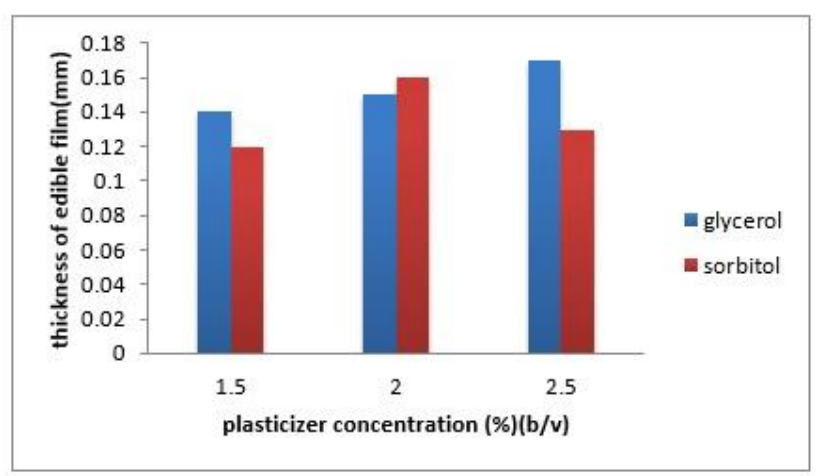

Figure 3. Edible film thickness

The value of edible film thickness shows that at concentration addition $1.5 \%, 2 \%$, and $2.5 \%(\mathrm{~b} / \mathrm{v})$ and sorbitol concentration addition $1.5 \%, 2 \%$, and $2.5 \%(\mathrm{~b} / \mathrm{v})$ experienced improvement in line with the addition of starch concentration, sorbitol, and glycerol. In the samples of edible film G1, G2, and G3 with glycerol addition obtained different results such as $0.14 \mathrm{~mm}, 0.15 \mathrm{~mm}$, and $0.17 \mathrm{~mm}$. While at G3 edible film obtained bigger value of thickness compared to edible film G1 
and G2. Then at edible film samples S1, S2, and S3 with sorbitol addition also obtained different results such as 0.12 $\mathrm{mm}, 0.16 \mathrm{~mm}$, and $0.13 \mathrm{~mm}$. At S2 film edible also obtained bigger thickness value compared to edible film of S1 and S3 (Figure 3).

Edible film thickness is influenced by the wide of print, solution volume, and the number of total solids in the solution [19]. The existence of edible film thickness G1-G3 and S1-S3 because starch, glycerol, and sorbitol concentration got increased until giving total solid improvement in the solution which caused the increase of edible film thickness. This is caused by glycerol which has characteristic of easy to dissolve in the water [20]. Until the more glycerol concentration added, then it will increase the thickness of starch edible film [21].

\subsection{Tensile strength}

Tensile strength measurement aims to know the size of force needed for achieving maximum tensile at each edible film sample produced [22]. The value of edible film tensile strength obtained can be seen in Figure 4.

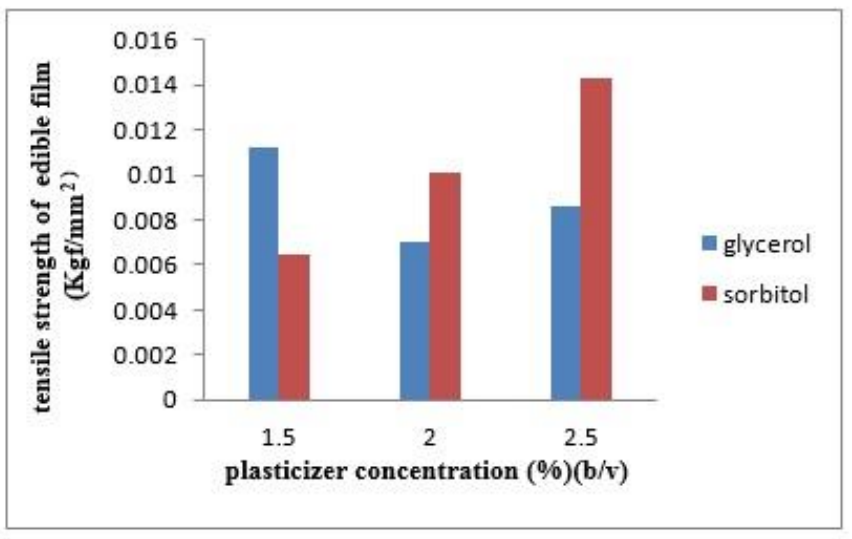

Figure 4. Edible film tensile strength

The highest average value of tensile strength of edible film sample is at sample G1 $0.011 \mathrm{~N} / \mathrm{mm}^{2}$, starch concentration $3 \%$ $(\mathrm{b} / \mathrm{v})$, glycerol concentration $1.5 \% \quad(\mathrm{~b} / \mathrm{v})$ and $\mathrm{CMC}$ concentration $1 \%(\mathrm{~b} / \mathrm{v})$ (Figure 4$)$. The increase of glycerol concentration shows fluctuate pattern towards the value of edible film tensile strength of durio seeds starch. This is cause by the polar nature $(-\mathrm{OH})$ around glycerol chain that can add the polymer hydrogen bond which replaces polymer bond in edible film of durio seeds starch. Plasticizer (glycerol) is the substance which has low molecule weight until it can enter the matrix of polymer polysaccharides and protein easily and improve film flexibility [23]

The results obtained from the addition of sorbitol 1,5\%,2\% and $2.5 \%(\mathrm{~b} / \mathrm{v})$ shows the highest average value of tensile strength of edible sample is at sample S3 with value 0.015 $\mathrm{N} / \mathrm{mm}^{2}$ with starch concentration $3 \%(\mathrm{~b} / \mathrm{v})$ or 3 gram, sorbitol concentration $2.5 \%(\mathrm{~b} / \mathrm{v})$ and $\mathrm{CMC}$ concentration $1 \%(\mathrm{~b} / \mathrm{v})$. The results obtained show that the higher the concentration of durio seeds starch then the power of edible film tensile strength and sorbitol plasticizer will be bigger. This occurs because of much more total solids dissolved and makes the cross bond at starch polymer formed tighter until it needs bigger force to pull edible film until broken off [24]. The tensile strength of edible film will increase in accordance with the increase of starch concentration added [22].

\subsection{Elongation}

Elongation value of edible film obtained can be seen in Figure 5.

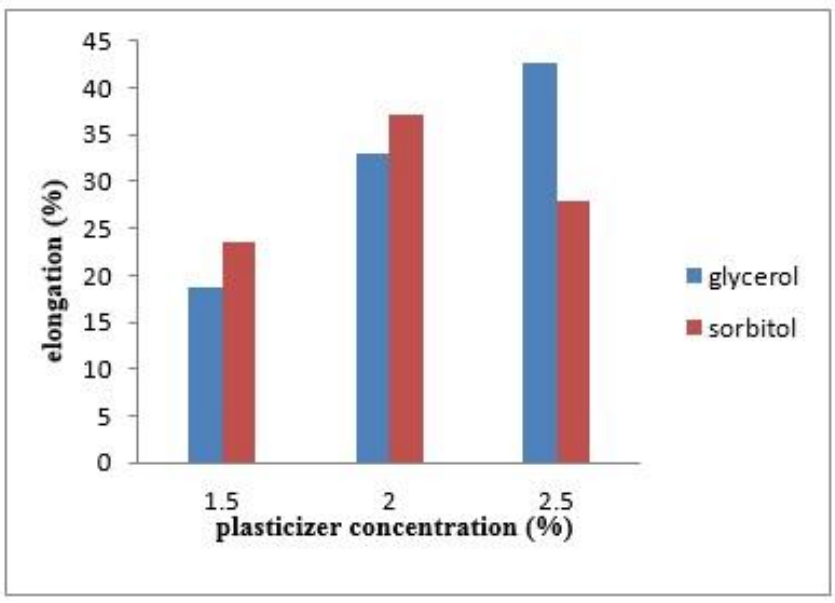

Figure 5. Edible film elongation

The elongation result of edible film from durio seeds starch through the addition of glycerol and sorbitol concentration can be seen that if glycerol concentration increases, then elongation percentage of edible film will tend to decrease (Figure 5). The starch addition which continues to increase accompanied by the addition of increase glycerol and sorbitol causes plastic characteristic of edible film will be lower and the elongation percentage will decrease [25]. The more plasticizer concentration then the cohesion bond among polymer will be smaller and edible film formed will be soft until edible film formed will be broken off easily [26]. Edible film elongation according to JIS (Japanese Industrial Standard) standard is minimal $70 \%$. From the result obtained the test edible film elongation at glycerol concentration $2.5 \%(\mathrm{~b} / \mathrm{v})$ in the amount of $42.75 \%$ and at sorbitol concentration $2 \%(b / v)$ in the amount of $37.13 \%$ which have not fulfilled JIS requirement.

\subsection{Elasticity}

The average value of elasticity obtained can be seen in Table 1

Table 1. Elasticity value

\begin{tabular}{cc}
\hline Edible Film Samples & Elasticity Value $\left(\mathbf{K g f} / \mathbf{m m}^{\mathbf{2}}\right)$ \\
\hline G1 & 0,0597 \\
G2 & 0,0213 \\
G3 & 0,0202 \\
S1 & 0,0275 \\
S2 & 0.0272 \\
S3 & 0,0511 \\
\hline
\end{tabular}

G1 and S3 Edible film obtain the highest elasticity value $0.0597 \mathrm{Kgf} / \mathrm{mm}^{2}$ and $0.0511 \mathrm{Kgf} / \mathrm{mm}^{2}$ which means edible film is more rigid (Table 1).

\subsection{Analysis of FTIR function group}

The result of FTIR analysis of durio seeds starch edible film, $\mathrm{CMC}$ and glycerol $(1.5,2,2.5) \mathrm{mL}$ is showed in Figure 6 . 


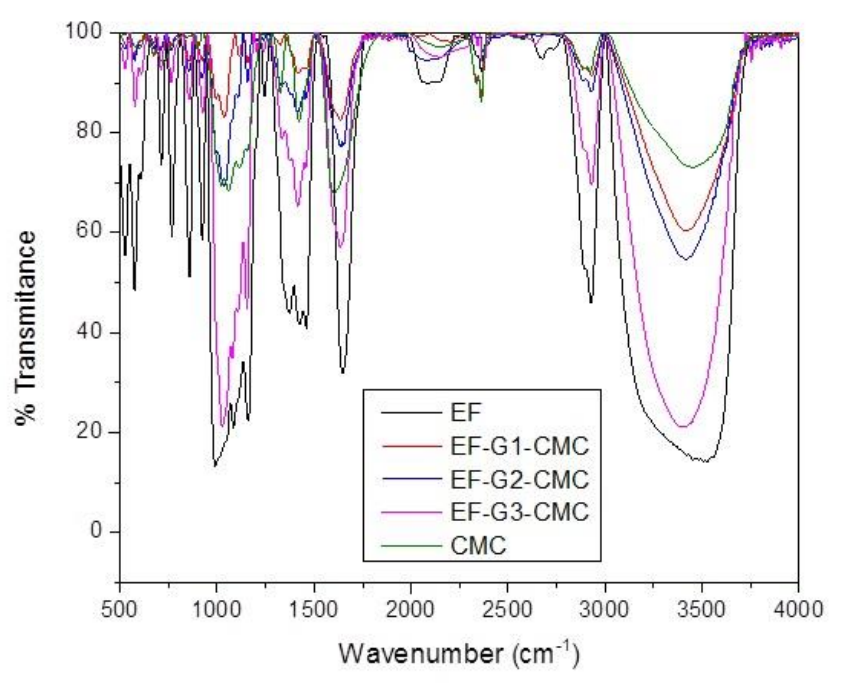

Figure 6. FTIR Spectrum of durio seeds starch edible film, $\mathrm{CMC}$ and glycerol $(1.5,2,2.5) \mathrm{mL}$

Based on Figure 6:

1) The result of function group identification result towards durio seeds starch, shows that detected $\mathrm{O}-\mathrm{H}$ group with hydrogen bond at wave number $3558.74 \mathrm{~cm}^{-1}$, C-H group (Alkane) at wave number $2927.94 \mathrm{~cm}^{-1}, \mathrm{C}=\mathrm{C}$ group (Alkene) at wave number $1641.42 \mathrm{~cm}^{-1}, \mathrm{C}-\mathrm{H}$ group (Alkene) strong at wave $1456.26 \mathrm{~cm}^{-1}, 1417.68 \mathrm{~cm}^{-1}$ and $1369.46 \mathrm{~cm}^{-1}$ and $\mathrm{C}=\mathrm{C}$ group (Alkane) strong at wave number $989.48 \mathrm{~cm}^{-1}$ [27].

2) The result of function group identification result towards $\mathrm{CMC}$, shows that detected $\mathrm{O}-\mathrm{H}$ group with hydrogen bond at wave number $3448.72 \mathrm{~cm}^{-1}$, C-H group (Alkane) at wave $2923.23 \mathrm{~cm}^{-1}, \mathrm{C}=\mathrm{C}$ group (Alkene) at wave $1635.64 \mathrm{~cm}^{-1}, \mathrm{C}-\mathrm{H}$ group (Alkane) strong at wave 1421.54 $\mathrm{cm}^{-1}$, C-O group (Alcohol, ether, carboxylate acid, ester) at wave $1056.99 \mathrm{~cm}^{-1}, \mathrm{NO}_{2}$ group (nitro compound) at wave $1327.03 \mathrm{~cm}^{-1}$ and $\mathrm{C}=\mathrm{C}$ group (Alkene) strong at wave $993.34 \mathrm{~cm}^{-1}$ [28].

3) The result of function group identification result towards durio seeds starch, with of the addition of:

- Glycerol $1.5 \mathrm{~mL}$, shows that detected O-H group with hydrogen bond at Wave Number $3387.00 \mathrm{~cm}^{-1}, \mathrm{C}-\mathrm{H}$ group (Alkane) at wave $2931.80 \mathrm{~cm}^{-1}, \mathrm{C}=\mathrm{C}$ group (Alkene) at wave $1645.28 \mathrm{~cm}^{-1}, \mathrm{C}-\mathrm{H}$ group (Alkene) strong at wave $1415.75 \mathrm{~cm}^{-1}$ and $\mathrm{C}=\mathrm{C}$ group (Alkene) strong at wave $925.83 \mathrm{~cm}^{-1}$ [28].

- Glycerol $2 \mathrm{~mL}$, shows that detected O-H group with hydrogen bond at Wave Number $3412.08 \mathrm{~cm}^{-1}$, C-H group (Alkane) at wave $2931.80 \mathrm{~cm}^{-1}, \mathrm{C}=\mathrm{C}$ group (Alkene) at wave $1637.56 \mathrm{~cm}^{-1}, \mathrm{C}-\mathrm{H}$ group (Alkene) strong at wave $1419.61 \mathrm{~cm}^{-1}$ and $\mathrm{C}=\mathrm{C}$ group (Alkene) strong at wave $923.90 \mathrm{~cm}^{-1}$ [28].

- Glycerol $2.5 \mathrm{~mL}$, shows that detected O-H group with hydrogen bond at Wave Number $3412.08 \mathrm{~cm}^{-1}, \mathrm{C}-\mathrm{H}$ group (Alkane) at wave $2933.73 \mathrm{~cm}^{-1}, \mathrm{C}=\mathrm{C}$ group (Alkene) at wave $1641.42 \mathrm{~cm}^{-1}, \mathrm{C}-\mathrm{H}$ group (Alkene) strong at wave $1417.68 \mathrm{~cm}^{-1}$ and $\mathrm{C}=\mathrm{C}$ group (Alkene) strong at wave $923.90 \mathrm{~cm}^{-1}[28]$.

The result of FTIR analysis of durio seeds starch edible film, $\mathrm{CMC}$ and sorbitol $(1.5,2,2.5) \mathrm{mL}$ is showed in Figure 7.

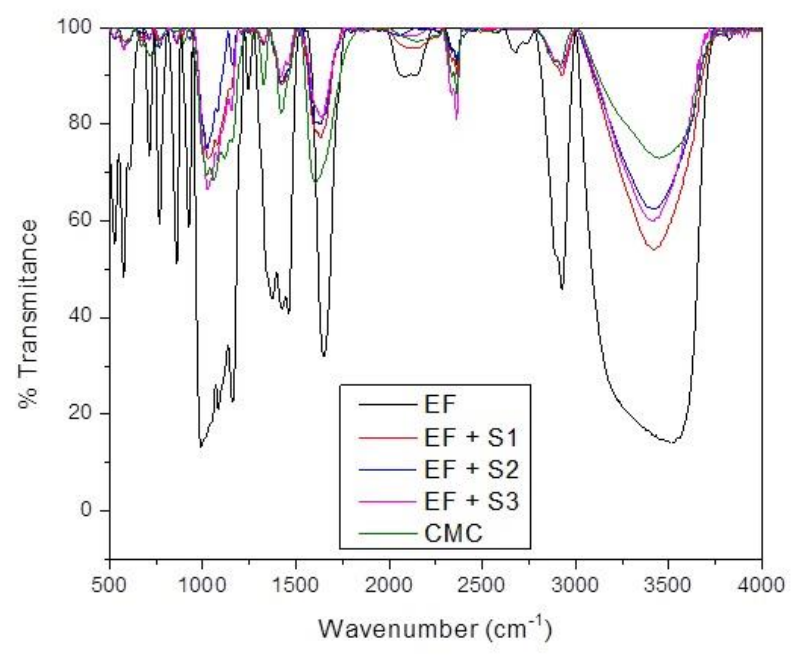

Figure 7. FTIR Spectrum of durio seeds starch edible film, $\mathrm{CMC}$ and sorbitol $(1.5,2,2.5) \mathrm{mL}$

The result of function group identification result towards durio seeds starch, with of the addition of:

- Sorbitol $1.5 \mathrm{~mL}$, shows that detected O-H group with hydrogen bond at Wave Number $3415.93 \mathrm{~cm}^{-1}, \mathrm{C}-\mathrm{H}$ group (Alkane) at wave $2926.01 \mathrm{~cm}^{-1}, \mathrm{C}=\mathrm{C}$ group (Alkene) at wave $1635.64 \mathrm{~cm}^{-1}, \mathrm{C}-\mathrm{H}$ group (Alkene) strong at wave $1419.61 \mathrm{~cm}^{-1}$ and $\mathrm{C}=\mathrm{C}$ group (Alkene) strong at wave $927.76 \mathrm{~cm}^{-1}$ [28].

- Sorbitol $2 \mathrm{~mL}$, shows that detected O-H group with hydrogen bond at Wave Number $3412.08 \mathrm{~cm}^{-1}$, C-H group (Alkane) at wave $2927.94 \mathrm{~cm}^{-1}, \mathrm{C}=\mathrm{C}$ group (Alkene) at wave $1641.42 \mathrm{~cm}^{-1}, \mathrm{C}-\mathrm{H}$ group (Alkene) strong at wave $1417.68 \mathrm{~cm}^{-1}$ and $\mathrm{C}=\mathrm{C}$ group (Alkene) strong at wave $929.69 \mathrm{~cm}^{-1}[28]$.

- Sorbitol $2.5 \mathrm{~mL}$, shows that detected O-H group with hydrogen bond at Wave Number $3412.08 \mathrm{~cm}^{-1}$, C-H group (Alkane) at wave $2927.94 \mathrm{~cm}^{-1}, \mathrm{C}=\mathrm{C}$ group (Alkene) at wave $1641.42 \mathrm{~cm}^{-1}, \mathrm{C}-\mathrm{H}$ group (Alkene) strong at wave $1417.68 \mathrm{~cm}^{-1}$ and $\mathrm{C}=\mathrm{C}$ group (Alkene) strong at wave $929.69 \mathrm{~cm}^{-1}[28]$.

Based on Figure 6 and Figure 7, then the identification result of Function Group at edible film with plasticizer glycerol type and sorbitol obtain the same Function Group with the function group of durio seeds starch and CMC. The result of edible film from mixture of durian seed starch and $\mathrm{CMC}$ with glycerol and sorbitol plasticizer not found the presence of new function group until by obtaining FTIR result then it can show that the process of making edible film in this research is Physics mixture process, by the existence of hydrogen bond between the chain. Hydrogen bond occurs when an oxygen atom molecule from plasticizer interacts with hydrogen from durian seed starch and CMC. The bigger the content of O-H Function Group, then the more hydrogen bond and boiling point owned by edible film will be higher also. The interaction of hydrogen bond obtained in each edible film is included into dipoles [29]. The result obtained shows that edible film with the addition of glycerol and sorbitol plasticizer have function group that is relatively almost the same with the components of edible film which has hydrophilic characteristic which can be seen by the existence of $\mathrm{O}-\mathrm{H}$ function group, by the existence of this function group then it shows that the edible film obtained can be degraded perfectly in the soil [30]. 


\section{$3.6 \mathrm{pH}$ test}

The examination result of edible film $\mathrm{pH}$ with mixture of starch+glycerol+CMC obtains 3 edible film samples with starch concentration $3 \%$ and glycerol $1.5 \%, 2 \%, 2.5 \%$ is $\mathrm{G} 1$ edible film sample with $\mathrm{pH} 6,77, \mathrm{G} 2$ with $\mathrm{pH} 6,82$ and $\mathrm{G} 3$ with $\mathrm{pH}$ 6.90. These show that edible film produced by the addition of glycerol is acid which means it can interact with another substance after added with active substance. While for the examination result of edible film $\mathrm{pH}$ with the mixture of starch+sorbitol+CMC obtains 3 edible film samples with starch concentration $3 \%$ and glycerol $1.5 \%, 2 \%, 2.5 \%$ are edible film sample S1 with $\mathrm{pH} 7.79$, S2 with $\mathrm{pH} 7.85$, and S3 with $\mathrm{pH} 7.95$. These show that edible film produced by the addition of glycerol is base which means it can interact with another substance after added with active substance.

\subsection{Biodegradability test}

Biodegradability test aims to know if certain material can be degraded well in the environment. In this research, biodegradability test was conducted by the assistance of EM4 bacteria. EM4 bacteria will result enzyme to degrade edible film by breaking polymer chain to be monomer [31]. Biodegradability testing was conducted by soaking edible film sample in EM4 (Effective Microorganism 4) in a chemical glass. The result of biodegradability test shows edible film of durio seeds starch can be degraded perfectly in 7 days while for commercial plastic can be degraded for 30 days. This shows that edible film of durio seeds starch can be degraded perfectly and faster compared to commercial plastic.

\subsection{Water absorption test} 8.

The result value of water absorption can be seen in Figure

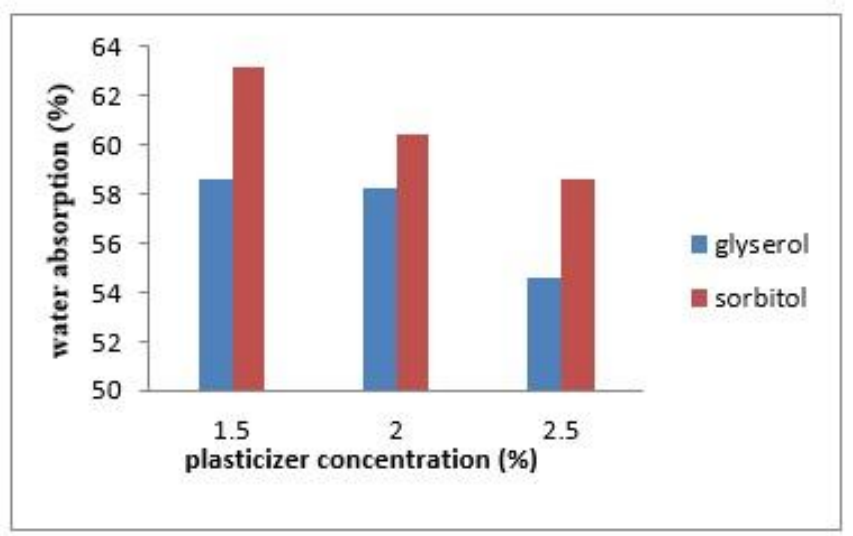

Figure 8. Edible film absorption

Water absorption of edible film produced at glycerol concentration addition $1.5 \%, 2 \%, 2.5 \%$ such as $58.57 \%$, $58.22 \%$, and $54.61 \%$. It can be seen in Figure 8 for G1 Edible Film which has the highest water absorption then for G3 edible film owns the lowest water absorption. While edible film water absorption of durian seed starch produced the higher sorbitol, concentration added then the lower its water absorption. Water absorption of edible film produced at glycerol concentration addition $1.5 \%, 2 \%, 2.5 \%$ such as $63.12 \%, 60.43 \%$, and $58.57 \%$. It can be seen in Figure 8 for S1 Edible Film which has the highest water absorption then for S3 edible film owns the lowest water absorption. Edible film which is made of more increase of plasticizer composition owns smaller water absorption. This is caused by the increase of internal hydrogel at intermolecular bond caused by the glycerol activity or sorbitol [32]. Starch is less resistant towards water because it has more hydroxyl group $(\mathrm{OH})$ until it absorbs much more water [33].

\subsection{Solubility test}

The value of solubility result of edible film can be seen in Figure 9. The best solubility value from glycerol and sorbitol addition is at the concentration addition $2.5 \%(\mathrm{~b} / \mathrm{v})$ are $40.89 \%$ and $27.56 \%$. (Figure 9). The addition of plasticizer concentration can increase edible film solubility because glycerol is hydrophilic until it is soluble in the water and also can increase solubility percentage of edible film [34]. This is the same with the addition of sorbitol plasticizer, the more sorbitol concentration, then the more increase the solubility in the water because sorbitol also has hydrophilic characteristic [35].

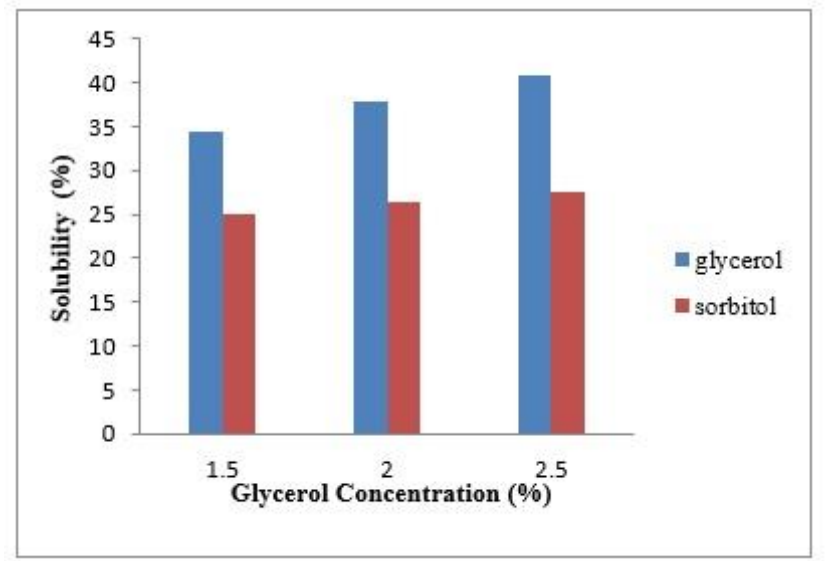

Figure 9. Edible film solubility

\subsection{The speed of water vapor transmission gravimetry method}

The result of water vapor transmission speed at the addition of glycerol plasticizer obtains the highest value of water vapor transmission speed at G3 is $0.2275 \mathrm{~g} / \mathrm{jamm}^{2}$ while for the lowest value is at $\mathrm{G} 1$ in the amount of $0,1565 \mathrm{~g} / \mathrm{jamm}^{2}$ and at $\mathrm{G} 2$ obtained the value $0.1868 \mathrm{~g} / \mathrm{jamm}^{2}$. Next for the result of water vapor transmission speed at the addition of sorbitol plasticizer obtained the highest value of water vapor transmission value at S3 in the amount of $0.3333 \mathrm{~g} / \mathrm{jamm}{ }^{2}$, at $\mathrm{S} 2$ is $0.3126 \mathrm{~g} / \mathrm{jamm}^{2}$ and at $\mathrm{S} 1$ is $0.2515 \mathrm{~g} / \mathrm{jamm}^{2}$ which is the lowest score. The concentration increases of plasticizer used make the speed of water vapor transmission is getting faster. Glycerol and sorbitol plasticizer have hydrophilic characteristic and can make edible film has high water vapor transmission speed by the increase of starch number used [2, $30,35]$.

\subsection{Shelf-life test}

Shelf-life test at cool temperature of durio seeds starch edible film is showed in Table 2 and the result of shelf-life test at room temperature is at Table 3. 
Table 2. Shelf-life test at cool temperature

\begin{tabular}{ccccc}
\hline No & Apple Treatment & Cool room temperature $\left({ }^{\circ} \mathbf{C}\right)$ & Shelf life (days) & Physical Condition \\
\hline 1. & Wrapped with edible film & 16 & 7 & Good, a bit wrinkle but not moldy \\
2. & Without packer & 16 & 3 & A bit wrinkle \\
\hline
\end{tabular}

Table 3. Shelf life at room temperature

\begin{tabular}{ccccc}
\hline No & Apple Treatment & Room Temperature $\left({ }^{\circ} \mathbf{C}\right)$ & Shelf life (days) & Physical Condition \\
\hline 1. & Wrapped with edible film & 30 & 5 & Good, a bit wrinkle but not moldy \\
2. & Wrapped with greaseproof paper & 30 & 3 & Wrinkle \\
3. & Without packer & 39 & 2 & Covered buy mushroom \\
\hline
\end{tabular}

Shelf-life test conducted obtains data of shelf life in room temperature $\left(30^{\circ} \mathrm{C}\right)$ for apple wrapped with edible film and can survive for 5 days, for able wrapped with greaseproof paper and without packer only survives for 2 days. While at cool temperature $\left(16^{\circ} \mathrm{C}\right)$ for apple wrapped with edible film can survive for 8 days and for apple without packer can survive only for 4 days. From the results obtained then it can be known that apple wrapped with edible film of Banggai tuber starch can survive longer compared to apple wrapped with greaseproof paper or without packer. This shows that the addition of glycerol and sorbitol plasticizers in making edible film can inhibit edible film storability. However, the storability of the material made of starch has short storability. The damage on starch occurs because starch at room temperature easily experiences moisture absorption until causing starch can be covered with mushrooms. Mushroom can cause starch base material quickly experiences damage [2, 30].

\section{CONCLUSIONS}

The research results obtain that the higher room temperature used then the water absorption, solubility, and tensile strength of edible film will decrease while the elongation percentage will increase. The more glycerol than water absorption and edible film elongation percentage increase while the tensile strength and edible film thickness decreases. The more sorbitol than the water absorption, tensile strength, and elongation percentage of edible film will decrease while edible film thickness increases.

The best treatment in this research was edible film with by adding $2.5 \%(\mathrm{w} / \mathrm{v})$ of glycerol and $2 \%(\mathrm{w} / \mathrm{v})$ of sorbitol.

The physical characteristics of the edible film are respectively: thickness $0.1700 \mathrm{~mm}$ and $0.1633 \mathrm{~mm}$, tensile strength $0.008 \mathrm{Kgf} / \mathrm{mm}^{2}$ and $0.010 \mathrm{Kgf} / \mathrm{mm}^{2}$, percent elongation $42.76 \%$ and $37.13 \%$, elasticity 0.0202 and 0.0272 . The chemical characteristics of edible film include: water absorption test of $58.22 \%$ and $60.43 \%$, solubility of $40.89 \%$ and $26.42 \%$, water vapor transmission rates of $0.2275 \mathrm{~g} /$ $\mathrm{jamm}^{2}$ and $0.3127 \mathrm{~g} / \mathrm{jamm}^{2}$, and $\mathrm{pH} 6.90$ and 7.85 . The results of functional group analysis (FTIR) show that the process of making edible films in this study is a physical mixing process. The shelf life of edible films at room temperature is 5 days and at cold temperature for 7 days. The biodegradability test showed that the edible film in this study could be completely degraded within 7 days.

\section{ACKNOWLEDGMENT}

The research was supported by DIPA research funding in
2020, Tadulako University.

\section{REFERENCES}

[1] Huda, T. (2007). Karakteristik fisikokimiawi film plastik biodegradable dari komposit pati singkong-ubi jalar. Jurnal Logika, PPST DPPM Universitas Islam Indonesia, 4(1).

[2] Rahmawati, S., Aulia, A., Nuryanti, S. (2020). The making and chacacterization of Banggai tuber (dioscores spp) edible film. International Journal of Advanced Science and Thechnology, 29(5).

[3] Aryanti, N. (2013). Biopolimer sebagai plastik ramah lingkungan. Buletin Teknologi Terapan Populer, 1(1): 228.

[4] González-Gutiérrez, J., Partal, P., García-Morales, M., Gallegos, C. (2011). Effect of processing on the viscoelastic, tensile and optical properties of albumen/starch-based bioplastics. Carbohydrate Polymers, 84(1): 308-315. https://doi.org/10.1016/j.carbpol.2010.11.040

[5] Darni, Y., Utami, H. (2009). Studi pembuatan dan karakteristik sifat mekanik dan hidrofobisitas bioplastik dari pati sorgum. Jurnal Rekayasa Kimia \& Lingkungan, 7(2): 88-93.

[6] Sulistriyono, A., Pratjojo, W., Widiarti, N. (2014). Sintesis dan Karakterisasi Plastik Edible Film dan Pektin Belimbing Wuluh Sebagai Pembungkus Wingko. Indonesian Journal of Chemical Science, 3(3).

[7] Arini, D., Ulum, M.S., Kasman, K. (2017). Pembuatan dan pengujian sifat mekanik plastik biodegradable berbasis tepung biji durian. Natural Science: Journal of Science and Technology, 6(3): 276-283. https://doi.org/10.22487/25411969.2017.v6.i3.9202

[8] Julianto, G.E., Ustadi, U., Husni, A. (2011). Karakterisasi Edible Film dari Gelatin Kulit Nila Merah dengan Penambahan Plasticizer Sorbitol dan Asam Palmitat. Jurnal Perikanan Universitas Gadjah Mada, 13(1): 27-34.

[9] Rambe, M.A.A. (2017). Pembuatan dan Karakterisasi Plastik Edible Film dengan Pemanfaatan Pati Kulit Ubi Kayu (Manihot Utilissima Pohl.) dan Keratin Bulu Ayam.

[10] Sjamsiah, S., Saokani, J., Lismawati, L. (2017). Karakteristik Edible Film dari Pati Kentang (Solanum Tuberosum L.) dengan Penambahan Gliserol. Al-Kimia, 5(2): $\quad$ 181-192. https://doi.org/10.24252/alkimia.v5i2.3932

[11] Jacoeb, A.M., Nugraha, R., Utari, S.P.S.D. (2014). Pembuatan edible film dari pati buah lindur dengan penambahan gliserol dan karaginan. Jurnal Pengolahan Hasil Perikanan Indonesia, 17(1): 14-21. 
https://doi.org/10.17844/jphpi.v17i1.8132

[12] Saleh, F.H., Nugroho, A.Y., Juliantama, M.R. (2017). Pembuatan Edible Film dari Pati Singkong sebagai Pengemas Makanan. Teknoin, 23(1). https://doi.org/10.20885/teknoin.vol23.iss1.art5

[13] Nofiandi, D., Ningsih, W., Putri, A.S.L. (2016). Pembuatan dan Karakterisasi Edible Film dari Poliblend Pati Sukun-Polivinil Alkohol dengan Propilenglikol sebagai Plasticizer. Jurnal Katalisator, 1(2).

[14] Zain, A.K., Nugraha, I. (2018). Sintesis dan Karakterisasi Komposit Edible Film Isolat Protein Ampas TahuMontmorillonit. Indonesian Journal of Materials Chemistry, 1(1): 19-25.

[15] Setiawan, H., Faizal, R., Amrullah, A. (2015). Penentuan kondisi optimum modifikasi konsentrasi plasticizer sorbitol pva pada sintesa plastik biodegradable berbahan dasar pati sorgum dan chitosan limbah kulit udang. Sainteknol: Jurnal Sains dan Teknologi, 13(1). https://doi.org/10.15294/sainteknol.v13i1.5333

[16] Setiani, W., Sudiarti, T., Rahmidar, L. (2013). Preparasi dan karakterisasi edible film dari poliblend pati sukunkitosan. Jurnal Kimia Valensi, 3(2).

[17] Harumarani, S., Ma'ruf, W.F. (2016). Pengaruh Perbedaan Konsentrasi Gliserol Pada Karakteristik Edible film Komposit Semirefined Karagenan Eucheuma Cottoni Dan Beeswax. Jurnal Pengolahan dan Bioteknologi Hasil Perikanan, 5(1): 101-105.

[18] Kamper, S.L., Fennema, O. (1984). Water vapor permeability of edible bilayer films. Journal of Food science, $\quad 49(6)$ : 1478-1481. https://doi.org/10.1111/j.1365-2621.1984.tb12825.x

[19] Park, J.W., Testin, R.F., Vergano, P.J., Park, H.J., Weller, C.L. (1996). Application of laminated edible films to potato chip packaging. Journal of Food Science, 61(4), 766-768. https://doi.org/10.1111/j.13652621.1996.tb12200.x

[20] Bertuzzi, M.A., Vidaurre, E.C., Armada, M., Gottifredi, J.C. (2007). Water vapor permeability of edible starch based films. Journal of food engineering, 80(3): 972-978. https://doi.org/10.1016/j.jfoodeng.2006.07.016

[21] Anandito, R.B.K., Bukhori, A. (2012). Pengaruh Gliserol Terhadap Karakteristik Edible Film Berbahan Dasar Tepung Jali (Coix Lacryma-Jobi L.). Jurnal Teknologi Hasil Pertanian, 5(1). https://doi.org/10.20961/jthp.v0i0.13534

[22] Krochta, J.M., Johnston, C.D.M. (1997). Edible and biodegradable polymer film. Journal of Food Technology, 51(2): 61-74.

[23] Bergo, P., Sobral, P.J.A. (2007). Effects of plasticizer on physical properties of pigskin gelatin films. Food Hydrocolloids, 21(8): 1285-1289. https://doi.org/10.1016/j.foodhyd.2006.09.014

[24] Cornelia, M., Anugrahati, N.A., Christina, C. (2012).
Pengaruh Penambahan Pati Bengkoang $\mathrm{T}$ erhadap Karakteristik Fisik dan Mekanik Edible Film. Jurnal Kimia dan Kemasan, 34(2): 263-271. https://doi.org/10.24817/jkk.v34i2.1862

[25] Su, J.F., Huang, Z., Yuan, X.Y., Wang, X.Y., Li, M. (2010). Structure and properties of carboxymethyl cellulose/soy protein isolate blend edible films crosslinked by Maillard reactions. Carbohydrate Polymers, $\quad 79(1)$ : 145-153. https://doi.org/10.1016/j.carbpol.2009.07.035

[26] Bourtoom, T. (2007). Effect of Some Process Parameters on the Properties of Edible Film Prepared from Starch. Department of Material Product Technology, Songkhala.

[27] Skoog, D.A., Holler, F.J., Crouch, S.R. (1998). Principles of Instrumental Analysis. Cengage learning, 837-847.

[28] Krochta, J.M., Baldwin, E.A., Nisperos-Carriedo, M.O. (1994). Edible Coatings and Films to Improve Food Quality. Technomic Publ. Co., Lancaster, PA, 1-379.

[29] Wardah, I., Hastuti, E. (2015). Pengaruh variasi komposisi gliserol dengan pati dari bonggol pisang, tongkol jagung, dan enceng gondok terhadap sifat fisis dan mekanis plastik biodegradable. Jurnal Neutrino: Jurnal Fisika dan Aplikasinya, 77-85. https://doi.org/10.18860/neu.v0i0.2994

[30] Teo, G., Suzuki, Y., Uratsu, S.L., Lampinen, B., Ormonde, N., Hu, W.K., Dandekar, A.M. (2006). Silencing leaf sorbitol synthesis alters long-distance partitioning and apple fruit quality. Proceedings of the National Academy of Sciences, 103(49): 18842-18847. https://doi.org/10.1073/pnas.0605873103

[31] Yuniwati, M. (2018). Pemanfaatan Umbi Gadung Dan Serat Daun Nanas Untuk Pembuatan Plastik Biodegradable. Jurnal Teknologi Technoscientia, 9(2).

[32] Rodríguez, M., Osés, J., Ziani, K., Mate, J.I. (2006). Combined effect of plasticizers and surfactants on the physical properties of starch based edible films. Food Research International, 39(8): 840-846. https://doi.org/10.1016/j.foodres.2006.04.002

[33] Fera, M. (2018). Kualitas fisik edible film yang diproduksi dari kombinasi gelatin kulit domba dan agar (Gracilaria sp). Journal of Food and Life Sciences, 2(1). https://doi.org/10.21776/ub.jfls.2018.002.01.05

[34] Unsa, L.K., Paramastri, G.A. (2018). Kajian jenis plasticizer campuran gliserol dan sorbitol terhadap sintesis dan karakterisasi edible film pati bonggol pisang sebagai pengemas buah apel. Jurnal Kompetensi Teknik, 10(1):

$35-47$. https://doi.org/10.15294/jkomtek.v10i1.17368

[35] Hidayati, S., Zuidar, A.S., Diani, A. (2015). Aplikasi sorbitol pada produksi biodegradable film dari nata de cassava. $\quad$ Reaktor, 15(3): 196-204. https://doi.org/10.14710/reaktor.15.3.195-203 